\title{
Safety and Efficacy of DPP4 Inhibitor and Basal Insulin in Type 2 Diabetes: An Updated Review and Challenging Clinical Scenarios
}

\author{
Fernando Gomez-Peralta (D) · Cristina Abreu • Sara Gomez-Rodriguez • \\ Rafael J. Barranco · Guillermo E. Umpierrez
}

Received: June 14, 2018 / Published online: August 16, 2018

(C) The Author(s) 2018

\begin{abstract}
The safety and efficacy of dipeptidyl peptidase- 4 (DPP4) inhibitors as monotherapy or in combination with other oral antidiabetic agents or basal insulin are well established. DPP4 inhibitors stimulate glucose-dependent insulin secretion and inhibit glucagon production. As monotherapy, they reduce the hemoglobin A1c level by about $0.6-0.8 \%$. The addition of a DPP4 inhibitor to basal insulin is an attractive option, because they lower both postprandial and fasting plasma glucose concentrations without increasing the risk of hypoglycemia or weight gain. The present review summarizes the extensive evidence on the combination therapy of DPP4 inhibitors and insulin-based regimens in patients with type 2 diabetes. We focus our
\end{abstract}

Enhanced digital features To view enhanced digital features for this article go to https://doi.org/10.6084/ m9.figshare.6945401.

F. Gomez-Peralta $(\bowtie) \cdot$ C. Abreu .

S. Gomez-Rodriguez

Endocrinology and Nutrition Unit, Segovia General

Hospital, Segovia, Spain

e-mail: fgomezperalta@gmail.com

R. J. Barranco

Department Health Sciences, University of Jaén, Jaén, Spain

G. E. Umpierrez

Department of Medicine, Emory University School of Medicine, Atlanta, GA, USA discussion on challenging clinical scenarios including patients with chronic renal impairment, elderly persons and hospitalized patients. The evidence indicates that these drugs are highly effective and safe in the elderly and in the presence of mild, moderate and severe renal failure improving glycemic control with low risk of hypoglycemia. In addition, several randomized-controlled trials have shown that the use of DPP4 inhibitors in combination with basal insulin represents an alternative to the basal-bolus insulin regimen in hospitalized patients with type 2 diabetes.

Keywords: Alogliptin; Basal insulin; DPP4 inhibitors; Glycemic control; Linagliptin; Saxagliptin; Sitagliptin; Type 2 diabetes; Vildagliptin

\section{INTRODUCTION}

Type 2 diabetes mellitus (T2D) is a complex and progressive disease with an alarming increase worldwide. The International Diabetes Federation estimates that there are about 415 million adults aged 20-79 with diabetes, including 193 million who are underdiagnosed [1]. Distressingly, by the end of 2040, 642 million people will be living with the disease. T2D is characterized by multiple pathophysiologic defects, including progressive $\beta$-cell dysfunction and 
insulin resistance in the liver and peripheral tissues [2]. Chronic hyperglycemia in diabetes is associated with increased risk of microvascular (nephropathy, retinopathy, neuropathy) and macrovascular (coronary artery, cerebrovascular or peripheral arterial disease) complications, leading to increased all-cause mortality [3]. Improved glycemic control to a target HbA1c concentration of $7.0 \%$ or lower is generally recommended to minimize the risk of longterm complications. However, about half of patients with diabetes remained with HbA1c $>7 \%$, and $\sim 15 \%$ with HbA1c $>9 \%$, which placed them at high risk for complications and associated medical and indirect costs [4].

Current pharmacologic agents focus on the multiple pathophysiologic disturbances of T2D aiming at increasing available insulin, reducing resistance to insulin, slowing gastric emptying and absorption of carbohydrates, or promoting urinary glucose excretion. Dipeptidyl peptidase4 (DPP4) inhibitors and GLP-1 receptor agonists (incretin agents) improve glucose control through several of these mechanisms, including a glucose-dependent reduction of postprandial glucagon or enhancement of insulin secretion as well as delayed gastric emptying [5-7]. DPP4 inhibitors are oral antidiabetic drugs that inhibit the enzyme DPP-4. DPP-4 is a ubiquitous enzyme expressed on the surface of most cell types that deactivates some bioactive peptides, including the incretin hormones glucose-dependent insulinotropic polypeptide (GIP) and GLP-1 $[8,9]$. Clinical studies to date indicate that DPP4 inhibitors increase native GLP-1, which effectively stimulates insulin secretion, suppresses glucagon release and improves glucose control in patients with T2D. These agents are well tolerated and have a low incidence of adverse effects [10].

A recent comprehensive systematic review of available add-on options to basal insulin treatment reported that all antidiabetic agents alone or in combination with basal insulin are effective in improving glycemic control [11]. However, the weight neutrality and lower risk of hypoglycemia of DPP4 inhibitors make them attractive in the recommended approach to patient-centered care and shared decision-making $[12,13]$. The present review summarizes recent data on the combination of DPP4 inhibitors with insulin-based regimens in the management of patients with T2D. Three clinical scenarios in which insulin therapy is indicated-chronic kidney disease, elderly persons and hospital care-illustrate the added value of DPP4 inhibitors and insulin combination.

\section{METHODS}

Two healthcare documentation specialists performed a comprehensive review of the literature. Randomized-controlled studies, observational studies and case series analyses published between 2001 and 2017 in which the main objective was to assess the efficacy and safety of DPP4 inhibitors, including alogliptin, sitagliptin, vildagliptin, saxagliptin and linagliptin, in combination with insulin in T2D were selected.

The search was conducted according to the PICO methodology [14], which included patients with type 2 diabetes mellitus ("P"), treatment with DPP4 inhibitors and insulin as the intervention ("I"), placebo as the comparator (" $\mathrm{C}$ "), and glycemic control, HbA1c and/or body weight as main outcomes ("O"). Studies in which these variables could not be identified were excluded. Using the electronic databases PubMed and MEDLINE (US National Library of Medicine, Bethesda, MD, USA), reports published in English and Spanish were considered. The MeSH terms 'diabetes mellitus, type 2,' 'metformin,' 'insulin,' 'dipeptidyl peptidase IV inhibitors,' 'alogliptin,' 'sitagliptin,' 'vildagliptin,' 'saxagliptin,' 'linagliptin,' 'kidney failure chronic' and 'aged' were used. Also, these descriptors combined with the free terms 'addon,' 'glucose-lowering,' 'elderly,' 'HbA1c,' 'weight' and 'incretin' limited to the title or title/abstract fields were used. No other restrictions regarding article type or text availability were included in the search strategy. However, customized searches with the filter 'Clinical Trial' were also performed. The reference lists of the identified articles were manually searched for additional studies that may have been overlooked using the computer-assisted search strategy. Moreover, we searched http://www. 
ClinicalTrials.gov for ongoing or completed clinical trials with DPP4 inhibitors added to basal insulin in T2D with inadequate glycemic control.

All articles were initially screened by reviewing the title and abstract; those articles in which the PICO approach could be applied were retrieved for full evaluation. Articles with the primary outcome aiming to assess the use of DPP4 inhibitors as add-on therapy to insulin were included in the analysis.

Selected studies were grouped according to each oral DPP4 inhibitor agent: alogliptin, sitagliptin, vildagliptin, saxagliptin and linagliptin. Studies focused on patients with T2D and renal impairment, the elderly population, and inpatient hospital and long-term care were independently evaluated. When a particular DPP4 inhibitor drug was primarily evaluated in patients with renal impairment or elderly subjects, results of these studies are presented in separate sections.

This article is based on previously conducted studies and does not contain any studies with human participants or animals performed by any of the authors.

\section{COMBINATION THERAPY OF DPP4 INHIBITORS AND INSULIN: GENERAL OVERVIEW}

\section{Alogliptin}

Results from randomized-controlled trials have shown that oral alogliptin improved glycemic control when administered as monotherapy, as dual therapy in combination with metformin, pioglitazone, a sulfonylurea, voglibose or insulin, or as triple therapy in combination with metformin plus pioglitazone [15]. Alogliptin was generally well tolerated and weight neutral, with a low risk of hypoglycemia.

Limited data are available on alogliptin treatment as add-on to insulin therapy (Table 1). In a randomized, double-blind, placebo-controlled study, alogliptin at daily doses of $25 \mathrm{mg}$ or $12.5 \mathrm{mg}$ was more effective than placebo to reduce HbA1c after 26 weeks of treatment, without causing weight gain or increasing the incidence of hypoglycemia [16]. Similar results were reported at 12 weeks in another trial of alogliptin plus insulin compared with placebo plus insulin conducted in Japanese patients [17]. In this trial, the incidence of AEs was comparable between groups, with no relevant increases in hypoglycemia or weight gain.

\section{Sitagliptin}

A 24-week randomized, double-blind, placebocontrolled study evaluated the efficacy and tolerability of sitagliptin when added to insulin therapy in T2D patients [18]. The addition of sitagliptin (100 mg/day) significantly reduced HbA1c by $0.6 \%$ compared with placebo $(0.0 \%)$, with a higher proportion of patients achieving an $\mathrm{HbA1c}$ level $<7 \%$. In that study, a similar HbA1c reduction was observed with different insulin formulations (long-acting, intermediate-acting or premixed insulins). In a different 24-week randomized trial, the addition of sitagliptin to insulin was significantly more effective at lowering HbA1c levels compared with placebo, as well as a $25 \%$ lower insulin requirement, and showed a significant reduction in hypoglycemia and weight gain compared with an insulin titration regimen [19].

In a 24-week prospective, randomized, openlabeled, controlled trial carried out in Japan, patients who were suboptimally controlled with at least twice daily injection of insulin were assigned to continuation of insulin treatment or addition of sitagliptin to insulin treatment [20]. Adding sitagliptin to insulin significantly reduced $\mathrm{HbA} 1 \mathrm{c}$ from $7.9 \% \pm 1.0 \%$ at baseline to $7.0 \% \pm 0.8 \%$ at week 24 , while there was no significant change in HbA1c in the insulin group. The incidence of hypoglycemia was also significantly reduced in the sitagliptin added group [20]. In a randomized placebo-controlled trial in Chinese patients on a stable insulin regimen for $\geq 10$ weeks, with or without metformin, and inadequate glycemic control, the addition of sitagliptin led to a significantly greater HbA1c reduction compared with placebo at week 24 [21]. A significantly higher proportion of patients taking sitagliptin (16\%) 
Table 1 Salient data of the main randomized studies of DPP4 inhibitors added to basal insulin therapy in patients with type 2 diabetes (T2D) and insufficient glycemic control

\begin{tabular}{|c|c|c|c|c|}
\hline References & Design & $\begin{array}{l}\text { Primary } \\
\text { outcome }\end{array}$ & $\begin{array}{l}\text { Patients and } \\
\text { treatment }\end{array}$ & Main findings \\
\hline $\begin{array}{l}\text { Rosenstock } \\
\text { et al. [16] }\end{array}$ & $\begin{array}{l}\text { Randomized } \\
\text { double-blind } \\
\text { placebo- } \\
\text { controlled }\end{array}$ & $\begin{array}{l}\text { Change of } \\
\text { HbAlc at } \\
\text { week } 26\end{array}$ & $\begin{array}{l}\text { Alogliptin } 12.5 \mathrm{mg} \\
\quad(n=131) \\
\text { Alogliptin } 25 \mathrm{mg} \\
\quad(n=129) \\
\text { Placebo }(n=130)\end{array}$ & $\begin{array}{l}\text { HbAlc change: }-0.71 \% \text { for } 25 \mathrm{mg} \text { dose, } \\
\quad-0.63 \% \text { for } 12.5 \mathrm{mg} \text { dose; }-0.13 \% \text { placebo } \\
\text { Decreases of HbAlc } \geq 0.5 \%, 1 \% \text { and } 1.5 \% \\
\text { significantly greater in alogliptin vs. placebo }\end{array}$ \\
\hline $\begin{array}{l}\text { Kaku et al. } \\
{[17]}\end{array}$ & $\begin{array}{l}\text { Randomized } \\
\text { double-blind } \\
\text { placebo- } \\
\text { controlled }\end{array}$ & $\begin{array}{l}\text { Change of } \\
\text { HbAlc at } \\
\text { week } 12\end{array}$ & $\begin{array}{l}\text { Alogliptin } 25 \mathrm{mg} \\
\quad(n=179)\end{array}$ & $\begin{array}{l}\text { HbAlc change: }-0.96 \% \text { alogliptin vs. }-0.29 \% \\
\text { placebo; intergroup difference }-0.66 \% \text {. } \\
\text { Proportions of patients who achieved HbAlc } \\
<8.0 \%,<7.0 \% \text { and }<6.0 \% \text { were } \\
\text { significantly higher in alogliptin group }\end{array}$ \\
\hline $\begin{array}{l}\text { Vilsbøll } \\
\text { et al. [18] }\end{array}$ & $\begin{array}{l}\text { Randomized } \\
\text { placebo- } \\
\text { controlled }\end{array}$ & $\begin{array}{l}\text { Change of } \\
\text { HbAlc at } \\
\text { week } 24\end{array}$ & $\begin{array}{l}\text { Sitagliptin } \\
\qquad 100 \mathrm{mg} / \text { day } \\
\quad(n=322) \\
\text { Placebo }(n=319)\end{array}$ & $\begin{array}{l}\text { HbAlc reduction } 0.6 \% \text { sitagliptin vs. } 0 \% \text { placebo } \\
\text { HbAlc }<7 \% \text { in } 13 \% \text { sitagliptin vs. } 5 \% \text { placebo } \\
\text { Higher reductions of fasting glucose }(15.0 \mathrm{mg} / \\
\mathrm{dl}) \text { and } 2 \text {-h postmeal }(36.1 \mathrm{mg} / \mathrm{dl}) \text { relative to } \\
\text { placebo }\end{array}$ \\
\hline $\begin{array}{l}\text { Hong et al. } \\
{[19]}\end{array}$ & $\begin{array}{l}\text { Randomized active- } \\
\text { competitor } \\
\text { parallel-group }\end{array}$ & $\begin{array}{l}\text { Change of } \\
\text { HbAlc at } \\
\text { week } 24\end{array}$ & $\begin{array}{l}\text { Sitagliptin } \\
\quad 100 \mathrm{mg} / \text { day } \\
\quad(n=70) \\
\text { Insulin-increasing } \\
\text { arm }(n=70)\end{array}$ & $\begin{array}{l}\text { HbAlc decreases }-0.6 \% \text { vs. }-0.2 \% \text {; } \\
\text { hypoglycemic events } 7.0 \text { vs. } 14.3 \text { per patient- } \\
\text { year; weight increase in the insulin-increasing } \\
\text { subjects }\end{array}$ \\
\hline $\begin{array}{l}\text { Shankar } \\
\text { et al. [21] }\end{array}$ & $\begin{array}{l}\text { Randomized } \\
\text { double-blind } \\
\text { placebo- } \\
\text { controlled }\end{array}$ & $\begin{array}{l}\text { Change of } \\
\text { HbAlc at } \\
\text { week } 24\end{array}$ & $\begin{array}{l}\text { Sitagliptin } \\
\qquad 100 \mathrm{mg} / \text { day } \\
\quad(n=234) \\
\text { Placebo }(n=233)\end{array}$ & $\begin{array}{l}\text { HbAlc reduction } 0.7 \% \text { vs. } 0.3 \% \text {; HbAlc target } \\
\text { of }<7 \%: 16 \% \text { vs. } 8 \% \text {; reduction of } 2 \text {-h } \\
\text { postmeal glucose } 26.5 \mathrm{mg} / \mathrm{dl} \text { relative to } \\
\text { placebo; no change of body weight }\end{array}$ \\
\hline $\begin{array}{l}\text { Mathieu } \\
\text { et al. [22] }\end{array}$ & $\begin{array}{l}\text { Randomized } \\
\text { double-blind } \\
\text { placebo- } \\
\text { controlled }\end{array}$ & $\begin{array}{l}\text { Change of } \\
\text { HbAlc at } \\
\text { week } 24\end{array}$ & $\begin{array}{l}\text { Sitagliptin } \\
\qquad 100 \mathrm{mg} / \text { day } \\
\quad(n=329) \\
\text { Placebo }(n=329)\end{array}$ & $\begin{array}{l}\text { HbAlc reduction }-1.3 \% \text { vs. }-09 \% \text {; increase } \\
\text { in dose of insulin was less in the sitagliptin } \\
\text { group }(-4.7 \mathrm{IU}) \text {; fewer patients in the } \\
\text { sitagliptin group experienced hypoglycemia }\end{array}$ \\
\hline $\begin{array}{l}\text { Yki- } \\
\text { Järvinen } \\
\text { et al. [24] }\end{array}$ & $\begin{array}{l}\text { Randomized } \\
\text { placebo- } \\
\text { controlled }\end{array}$ & $\begin{array}{l}\text { Change of } \\
\text { HbAlc at } \\
\text { week } 24\end{array}$ & $\begin{array}{l}\text { Linagliptin } \\
\qquad \begin{array}{l}5 \mathrm{mg} / \text { day } \\
(n=631)\end{array} \\
\text { Placebo }(n=630)\end{array}$ & $\begin{array}{l}\text { HbAlc mean change }-0.58 \% \text { vs. }+0.07 \% \text { at } \\
24 \text { weeks, }-0.48 \% \text { vs. }+0.05 \% \text { at } 52 \text { weeks; } \\
\text { HbAlc }<7.0 \% \text { after } 52 \text { weeks: } 16 \% \text { vs. } 7 \% \\
\text { reduction in HbAlc } \geq 0.5 \%: 37 \% \text { vs. } 17 \%\end{array}$ \\
\hline
\end{tabular}


Table 1 continued

\begin{tabular}{|c|c|c|c|c|}
\hline References & Design & $\begin{array}{l}\text { Primary } \\
\text { outcome }\end{array}$ & $\begin{array}{l}\text { Patients and } \\
\text { treatment }\end{array}$ & Main findings \\
\hline $\begin{array}{l}\text { Sheu et al. } \\
{[25]}\end{array}$ & $\begin{array}{l}\text { Randomized } \\
\text { placebo- } \\
\text { controlled (post } \\
\text { hoc analysis) }\end{array}$ & $\begin{array}{l}\text { Change of } \\
\text { HbAlc at } \\
\text { week } 24\end{array}$ & $\begin{array}{l}\text { Linagliptin } \\
\qquad \begin{array}{l}5 \mathrm{mg} / \text { day } \\
(n=80)\end{array} \\
\text { Placebo }(n=74)\end{array}$ & $\begin{array}{l}\text { HbAlc placebo-corrected mean change was } \\
-0.9 \% \pm 0.1 \% \text { at weeks } 24 \text { and } 52 \text {; changes } \\
\text { in mean body weight }-0.67 \text { vs. }-0.38 \mathrm{~kg}\end{array}$ \\
\hline $\begin{array}{l}\text { Durán- } \\
\text { Garcia } \\
\text { et al. [26] }\end{array}$ & $\begin{array}{l}\text { Randomized } \\
\text { placebo- } \\
\text { controlled (post } \\
\text { hoc analysis) }\end{array}$ & $\begin{array}{l}\text { Change of } \\
\text { HbAlc at } \\
\text { week } 24\end{array}$ & $\begin{array}{l}\text { Linagliptin } \\
\qquad \begin{array}{l}5 \mathrm{mg} / \text { day } \\
(n=475)\end{array} \\
\text { Placebo }(n=475\end{array}$ & $\begin{array}{l}\text { HbAlc adjusted mean change }-0.63 \% \text { vs. } 0.04 \\
\text { at week } 24 ; \mathrm{HbA} 1 \mathrm{c} \leq 7 \%: 16.4 \% \text { vs. } 6.5 \% \text { at } \\
\text { week } 52 \text {; placebo-corrected adjusted mean } \\
\text { reduction of fasting plasma glucose }-0.8 \mathrm{mmol} / \\
1 \text { at week } 24 ; \text { mean change of insulin dose } \\
2.3 \mathrm{U} \text { vs. } 4.0 \mathrm{U} \text { at week } 52 \text { versus baseline }\end{array}$ \\
\hline $\begin{array}{l}\text { Barnett } \\
\text { et al. [27] }\end{array}$ & $\begin{array}{l}\text { Randomized } \\
\text { placebo- } \\
\text { controlled }\end{array}$ & $\begin{array}{l}\text { Change of } \\
\text { HbAlc at } \\
\text { week } 24\end{array}$ & $\begin{array}{l}\text { Saxagliptin } \\
\qquad \begin{array}{l}5 \mathrm{mg} / \text { day } \\
(n=304)\end{array} \\
\text { Placebo }(n=151)\end{array}$ & $\begin{array}{l}\text { HbAlc change }-0.73 \% \text { vs. }-0.32 \% \text {; HAlc } \\
\quad<7 \%: 17.3 \% \text { vs. } 6.7 \% \text {; adjusted-mean change } \\
\text { fasting plasma glucose }-10 \text { vs. }-6 \mathrm{mg} / \mathrm{dl}\end{array}$ \\
\hline $\begin{array}{l}\text { Barnett } \\
\text { et al. [28] }\end{array}$ & $\begin{array}{l}\text { Randomized } \\
\text { placebo- } \\
\text { controlled }\end{array}$ & $\begin{array}{l}\text { Change of } \\
\text { HbAlc at } \\
\text { week } 52\end{array}$ & $\begin{array}{l}\text { Saxagliptin } \\
\qquad \begin{array}{l}5 \mathrm{mg} / \text { day } \\
(n=304)\end{array} \\
\text { Placebo }(n=151)\end{array}$ & $\begin{array}{l}\text { Adjusted mean change HbAlc }-0.75 \% \text { vs. } \\
-0.38 \% \text {; adjusted between-group difference } \\
-0.37 \% \text {; HbAlc }<7 \%: 21.3 \% \text { vs. } 8.7 \% \text {; } \\
\text { increase mean total insulin dose } 5.67 \text { vs. } \\
6.67 \mathrm{U} \text {; similar results in metformin-treated } \\
\text { patients }\end{array}$ \\
\hline $\begin{array}{l}\text { Li et al. } \\
\text { [29] }\end{array}$ & $\begin{array}{l}\text { Randomized- } \\
\text { controlled open } \\
\text { label }\end{array}$ & $\begin{array}{l}\text { Changes of } \\
\text { MAGE } \\
\text { by CGM }\end{array}$ & $\begin{array}{l}\text { Saxagliptin } \\
\qquad \begin{array}{l}5 \mathrm{mg} / \mathrm{day} \\
(n=31)\end{array} \\
\text { Continuous } \\
\text { subcutaneous } \\
\text { insulin infusion } \\
(n=38)\end{array}$ & $\begin{array}{l}\text { After } 4 \text { weeks of therapy, glycemic control } \\
\text { reached in } 3.62 \text { vs. } 4.54 \text { days; total daily dose } \\
\text { insulin } 16.16 \text { vs. } 21.12 \text { U; MAGE } 2.47 \text { vs. } \\
\text { 3.37; hourly mean glucose levels } \\
\text { (0:00-6:00 a.m.) lower in the saxagliptin } \\
\text { group }\end{array}$ \\
\hline $\begin{array}{l}\text { Fonseca } \\
\text { et al. [30] }\end{array}$ & $\begin{array}{l}\text { Randomized } \\
\text { placebo- } \\
\text { controlled }\end{array}$ & $\begin{array}{l}\text { Change of } \\
\text { HbAlc at } \\
\text { week } 24\end{array}$ & $\begin{array}{l}\text { Vildagliptin } 50 \mathrm{mg} \\
\text { bid }(n=144) \\
\text { Placebo }(n=152)\end{array}$ & $\begin{array}{l}\text { HbAlc mean change }-0.5 \text { vs. }-0.2 \% \\
\text { (between-group difference }-0.3 \% \text { ); increase } \\
\text { in total daily insulin dose }+1.2 \text { vs. }+4.1 \mathrm{U} \text {; } \\
\text { hypoglycemia events } 1.95 \text { vs. } 2.96 \text { per patient- } \\
\text { year (severe } 0 \text { vs. } 0.10 \text { ) }\end{array}$ \\
\hline $\begin{array}{l}\text { Kothny } \\
\text { et al. [32] }\end{array}$ & $\begin{array}{c}\text { Randomized } \\
\text { placebo- } \\
\text { controlled }\end{array}$ & $\begin{array}{l}\text { Change of } \\
\text { HbAlc at } \\
\text { week } 24\end{array}$ & $\begin{array}{l}\text { Vildagliptin } 50 \mathrm{mg} \\
\text { bid }(n=228) \\
\text { Placebo }(n=221)\end{array}$ & $\begin{array}{l}\text { HbAlc mean change }-0.8 \text { vs. }-0.1 \% \\
\text { (between-group difference }-0.7 \% \text {; }-0.6 \% \text { in } \\
\text { the presence of metformin, }-0.8 \% \text { without } \\
\text { metformin); similar hypoglycemic events } \\
\text { ( } 8.4 \% \text { vs. } 7.2 \%) \text {; no weight gain }\end{array}$ \\
\hline
\end{tabular}


Table 1 continued

\begin{tabular}{|c|c|c|c|c|}
\hline References & Design & $\begin{array}{l}\text { Primary } \\
\text { outcome }\end{array}$ & $\begin{array}{l}\text { Patients and } \\
\text { treatment }\end{array}$ & Main findings \\
\hline $\begin{array}{l}\text { Hirose et al. } \\
\text { [33] }\end{array}$ & $\begin{array}{l}\text { Randomized } \\
\text { placebo- } \\
\text { controlled }\end{array}$ & $\begin{array}{l}\text { Change of } \\
\text { HbAlc at } \\
\text { week } 12\end{array}$ & $\begin{array}{c}\text { Vildagliptin } 50 \mathrm{mg} \\
\text { bid }(n=76) \\
\text { Placebo }(n=75)\end{array}$ & $\begin{array}{l}\text { HbAlc mean change }-1.01 \% \text { vs. }-0.11 \% \\
\text { (between-group difference }-0.91 \% \text { ); HbAlc } \\
<7 \%: 50 \% \text { vs. } 3.9 \% \text {; reductions in FPG } \\
\text { higher in the vildagliptin group }\end{array}$ \\
\hline $\begin{array}{l}\text { Ning et al. } \\
{[34]}\end{array}$ & $\begin{array}{l}\text { Randomized } \\
\text { placebo- } \\
\text { controlled }\end{array}$ & $\begin{array}{l}\text { Change of } \\
\text { HbAlc at } \\
\text { week } 24\end{array}$ & $\begin{array}{l}\text { Vildagliptin } 50 \mathrm{mg} \\
\quad \text { bid }(n=146) \\
\text { Placebo }(n=147)\end{array}$ & $\begin{array}{l}\text { Adjusted mean change HbAlc }-1.08 \% \text { vs. } \\
-0.38 \% \text { (between-group difference }-0.7 \% \text { ); } \\
\text { HbAlc }<7 \%: 23.6 \% \text { vs. } 11.2 \% \text {; hypoglycemia } \\
2.7 \% \text { vs. } 5.4 \%\end{array}$ \\
\hline
\end{tabular}

$M A G E$ mean amplitude glycemic excursion, $C G M$ continuous glucose monitoring, bid twice a day, $F P G$ fasting plasma glucose

had an HbA1c of $<7.0 \%$ compared with placebo $(8 \%)$ at week 24 . Also, the addition of sitagliptin significantly reduced 2 -h postmeal glucose by $26.5 \mathrm{mg} / \mathrm{dl}$ relative to placebo. Neither group had a significant change from baseline in body weight [21]. The addition of sitagliptin prior to intensive titration of basal insulin glargine has been shown to reduce the insulin requirements while providing superior glycemic control and less hypoglycemia compared with an insulin-titration regimen [22] (Table 1).

In a study using continuous glucose monitoring (CGM), the addition of sitagliptin led to significant decreases in 24-h mean glucose levels and reduction in glycemic variability compared with insulin therapy alone [23].

\section{Linagliptin}

The long-term effect of linagliptin as add-on therapy to basal insulin alone or in combination with metformin and/or pioglitazone was evaluated in a 52-week phase 3 randomized, placebo-controlled study [24] (Table 1). The adjusted mean changes in HbA1c from baseline were significantly higher in the linagliptin than placebo group, with treatment differences maintained for 76 weeks. Also, the proportion of patients with a reduction in HbA1c $\geq 0.5 \%$ was higher in the linagliptin group without an increase in hypoglycemia or body weight.
Similar results were obtained in a post hoc analysis in the subset of Asian patients [25] as well as in a subanalysis of participants on basal insulin and also on metformin [26].

\section{Saxagliptin}

The efficacy and safety of saxagliptin as add-on therapy were evaluated in a randomized placebo-controlled study in which 455 patients with T2D with inadequate glycemic control were on insulin alone [27] (Table 1). Patients were assigned $2: 1$ to receive saxagliptin ( $5 \mathrm{mg}$ /day) or placebo for 24 weeks. Patients treated with saxagliptin had significantly greater reductions of $\mathrm{HbA} 1 \mathrm{c}$ and postprandial glucose at 24 weeks than placebo. The difference in the proportion of patients achieving an HbA1c value $<7 \%$ was $17.3 \%$ and $6.7 \%$ of patients in the saxagliptin and placebo groups, respectively. HbA1c reduction in this study was not different between patients using metformin or not. Changes in body weight and confirmed hypoglycemia were similar in both groups. The favorable results associated with the combined use of saxagliptin and basal insulin were confirmed in a 28-week extension analysis of the same trial [28]. A randomized-controlled openlabel study using CGM in patients with T2D treated with continuous subcutaneous insulin infusion also showed saxagliptin improved 
glycemic control with lower insulin dose requirements [29].

\section{Vildagliptin}

Fonseca et al. [30] published the first study with vildagliptin in combination with insulin in 2007. In this 24-week randomized, doubleblind, placebo-controlled trial, HbA1c levels decreased by $-0.3 \%$ compared with placebo, without differences in body weight. Lower number and severity of hypoglycemic episodes were reported with vildagliptin compared with placebo. In a double-blind 28-week extension (overall treatment period 1 year), the hypoglycemic benefit was still evident and the improvement in glycemic control was sustained in patients continuing on vildagliptin $50 \mathrm{mg}$ twice a day [31]. A different 24-week randomized, double-blind study compared the effects of vildagliptin (50 $\mathrm{mg}$ twice a day) and placebo as add-on to ongoing insulin therapy, with or without metformin [32]. Vildagliptin reduced HbA1c by $0.8 \%$, with a between-group difference of $-0.7 \%$ compared with placebo. Treatment was not associated with weight gain or with increased risk of hypoglycemia. In two additional randomized-controlled studies in Japanese [33] and Asian, predominantly Chinese, patients with $\mathrm{T} 2 \mathrm{D}$ and inadequate diabetes control, the addition of vildagliptin to basal insulin, with or without concomitant metformin, significantly improved glycemic control without an increased risk of hypoglycemia [33, 34].

\section{Real-World Studies on the Combination of DPP4 Inhibitors and Insulin}

Two real-world studies have reported improvements in glycemic control in patients with T2D inadequately controlled on insulin treated with the addition of DPP4 inhibitors without causing significant weight gain or increasing the incidence of hypoglycemia $[35,36]$. The role of DPP4 inhibitors added to basal insulin has also been tested on a real-world basis in a particular clinical situation after switching from premixed insulin to basal insulin [37]. Administering
DPP4 inhibitors within this regimen may contribute to improving patients' glycemia, with a favorable weight-change profile and without increasing hypoglycemia risk.

\section{DPP4 INHIBITORS IN CHRONIC RENAL DISEASE}

Diabetic nephropathy is now the most common cause of chronic kidney disease (CKD) [38]. A cross-sectional analysis of adults with T2D based on the US National Health and Nutrition Examination Survey (NHANES) during 2007-2012 showed a CKD prevalence of 38.3\% [39]. Kidney involvement both directly and indirectly increases the damage of other organs and increases morbidity and mortality in patients with diabetes.

Although it has been widely recognized that prevention and early diagnosis of diabetic nephropathy improve long-term outcomes, management of hyperglycemia in patients with $\mathrm{CKD}$ is especially challenging, mainly because of changes in the renal excretion of antidiabetic drugs and comorbidities frequently present in these patients. Hypoglycemia and depletion of volume-associated adverse events risks are increased. The choice of antidiabetic agents for the management of patients with T2D and CKD is limited. Some pharmacologic classes are contraindicated in moderate or severe CKD, such as metformin, sulfonylureas and SGLT2 inhibitors. Insulin has been considered the safe choice for treating patients with kidney injury [40]. However, it requires a delicate dose adjustment because of changes in its duration of action and the augmented hypoglycemic risk in CKD [41].

Available evidence indicates that the use of DPP4 inhibitors effectively lowers HbA1c and may be safe in patients at various stages of renal insufficiency [42-51]. All DPP4 inhibitors are appropriate pharmacotherapeutic choices in patients with declining renal function, with linagliptin affording the added advantage of not requiring dose adjustment because it is not excreted through the kidney [48]. Recommendations for the use of DPP4 inhibitors in the 
presence of renal impairment are shown in Table 2.

Few studies have assessed the efficacy of DPP4 inhibitors as add-on therapy in patients with T2D and CKD. In an analysis of 811 participants in two phase- 3 randomized placebocontrolled trials of linagliptin, placebo-adjusted mean HbA1c changes from baseline were - 0.59\% (mild renal impairment) and - 0.69\% (moderate renal impairment) after 24 weeks and $-0.43 \%$ (severe renal impairment) after 12 weeks [49] of therapy. Frequency of hypoglycemia in patients treated with linagliptin with mild, moderate and severe renal impairment was $34.9 \%, 35.6 \%$ and $66.7 \%$, respectively, compared with $37.5 \%, 39.7 \%$ and $49.1 \%$ in patients treated with placebo. Episodes of severe hypoglycemia were low $(<5.6 \%)$ in both treatment arms [49]. A subanalysis of a 24 -week randomized placebo-controlled study of vildagliptin $50 \mathrm{mg} /$ day in 178 patients with T2D and

Table 2 Use of DPP4 inhibitors in patients with type 2 diabetes and renal function impairment

\begin{tabular}{|c|c|}
\hline Drug & Comment \\
\hline Alogliptin & $\begin{array}{l}\text { Doses should be halved in moderate-to } \\
\text { severe renal failure } \\
\text { eGFR } 30-50 \mathrm{~mL} / \mathrm{min} / 1.73 \mathrm{~m}^{2} \text { : halve doses } \\
\text { eGFR }<30 \mathrm{~mL} / \mathrm{min} / 1.73 \mathrm{~m}^{2} \text { : quarter doses }\end{array}$ \\
\hline Linagliptin & Dose adjustment is not needed \\
\hline Sitagliptin & $\begin{array}{l}\text { Doses should be halved in moderate-to } \\
\text { severe renal failure } \\
\text { Should be avoided in end-stage renal disease } \\
\text { or hemodialysis }\end{array}$ \\
\hline Sitagliptin & $\begin{array}{l}\text { Doses should be halved in moderate-to } \\
\text { severe renal failure } \\
\text { eGFR } 30-50 \mathrm{~mL} / \mathrm{min} / 1.73 \mathrm{~m}^{2} \text { : halve doses } \\
\text { eGFR }<30 \mathrm{~mL} / \mathrm{min} / 1.73 \mathrm{~m}^{2} \text { : quarter doses }\end{array}$ \\
\hline Vildagliptin & $\begin{array}{l}\text { Doses should be halved in moderate-to } \\
\text { severe renal failure } \\
\text { Use with caution in end-stage renal disease } \\
\text { or hemodialysis }\end{array}$ \\
\hline
\end{tabular}

eGFR estimated glomerular filtration rate renal disease, including patients with severe renal impairment (eGFR $<30 \mathrm{ml} / \mathrm{min} / 1.73 \mathrm{~m}^{2}$ ) while receiving ongoing insulin therapy reported that vildagliptin is a suitable treatment option in these patients [50]. The adjusted mean change in HbA1c from baseline $(7.7 \% \pm 0.1 \%)$ was $-0.9 \% \pm 0.4 \%$ and the between-treatment difference was $-0.6 \% \pm 0.2 \%$. The percentage of patients achieving endpoint HbA1c $<7.0 \%$ was $45.2 \%$ with vildagliptin and $22.8 \%$ with placebo. Vildagliptin and placebo had comparable hypoglycemic profiles and did not cause weight gain.

In summary, DPP4 inhibitors are a useful treatment option in people with T2D and CKD. DPP4 inhibitors, alone or in combination with insulin, are an effective and safe option across a wide range of renal functions [51].

\section{DPP4 INHIBITOR USE IN ELDERLY PATIENTS}

Treatment of T2D in the elderly is a major challenge because of the heterogeneity of this population with different functional and cognitive capacities, the presence of comorbidities and greater risk of hypoglycemia [52]. To minimize the risk of hypoglycemia and maximize the benefits of glycemic control, guidelines typically recommend individualizing HbA1c targets based on life expectancy, functional status and individual goals [53]. Safety is more important than reduction of HbA1c in the elderly. Although many elderly patients with T2D require insulin therapy to achieve and maintain glycemic control, treatment should be tailored to meet the needs of each individual [54]. The need to set individualized HbA1c targets using agents associated with a low risk of hypoglycemia has been suggested [55]. Metformin is the drug of choice, but its use is limited by the presence of gastrointestinal side effects, weight loss and reduced kidney function in the elderly population [53]. The use of DPP4 inhibitors has been shown effective in the elderly and frail population [55].

The results of a 6-month open randomizedcontrolled trial (Linagliptin-LTC Trial) in 140 elderly residents with T2D in long-term care 
facilities treated with linagliptin $(5 \mathrm{mg} /$ day) or with low-dose basal insulin (starting dose $0.1 \mathrm{U} /$ $\mathrm{kg}$ /day), with or without metformin, were recently reported [56]. The primary outcome was the mean difference in daily fasting or premeal blood glucose. Treatment with linagliptin resulted in similar glycemic control but a significantly lower risk of hypoglycemia (<70 mg/dl, 3\% vs. 37\%) compared with basal insulin therapy.

A pooled analysis of ten studies of 24-week duration with vildagliptin (50 $\mathrm{mg}$ twice daily) in 301 patients $\geq 75$ years showed that this agent was effective and well tolerated [57]. Results of a 24-week randomized placebo-controlled study of linagliptin ( $5 \mathrm{mg} /$ day) administered because of insufficient glycemic control despite metformin and/or sulfonylurea and/or insulin therapy in 241 patients aged $\geq 70$ years showed the adjusted mean change from baseline in HbA1c between linagliptin and the placebo was $-0.64 \%$ and $-1.15 \mathrm{mmol} / \mathrm{l}$ in fasting blood glucose [58]. The target treatment outcome of HbA1c $<7.0 \%$ was achieved significantly more often in patients on linagliptin treatment than in those with placebo (38.9\% vs. $8.3 \%)$. Hypoglycemia was the most common adverse event in both groups, but did not differ between groups. Similar favorable results were obtained in a 24-week randomized placebocontrolled study of combined treatment of vildagliptin and insulin [30]. In a pre-planned subgroup analysis of elderly patients aged 65 years or more, the adjusted mean change of $\mathrm{HbA1c}$ was $-0.7 \% \pm 0.1 \%$ during treatment with vildagliptin and $-0.1 \% \pm 0.1 \%$ during placebo administration (between-group difference $-0.6 \%)$. Confirmed hypoglycemia was somewhat lower in the vildagliptin group (2.32 vs. 2.64 events per patient-year). Elderly subjects can have greater postprandial glucagon and glucose levels than younger people; therefore, suppression of inappropriate glucagon secretion mediated by vildagliptin may explain the higher efficacy observed in an elderly population with T2D [30]. In summary, it seems that combined treatment of DPP4 inhibitors and insulin is effective in achieving glycemic control in elderly patients with T2D.

\section{DPP4 INHIBITORS IN HOSPITALIZED PATIENTS}

Randomized clinical trials carried out in critically and non-critically ill medical and surgical patients have shown that improvement of glycemic control reduced the risk of comorbidities such as systemic infections, length of hospital stay [66-68] and mortality [59-61]. Insulin therapy is required for glycemic control in a considerable proportion of patients in the hospital [62]. Some of them are treated with intravenous infusion during acute and severe intercurrent illness (as in the ICU). Subcutaneous insulin administration is used more frequently in non-critical wards. Clinical guidelines recommend basal-bolus insulin regimens as the standard of care for these patients with T2D [63, 64]. However, basal-bolus insulin regimens require multiple daily insulin injections and carry a substantial risk of hypoglycemia, reported in up to $32 \%$ of non-ICU patients with T2D [65]. Thus, simple regimens that result in similar glycemic efficacy to basalbolus insulin with less frequency of hypoglycemia are needed to improve care for noncritically ill patients with diabetes.

Recent randomized-controlled studies of non-critically ill medical and surgical patients have reported that treatment with a DPP4 inhibitor alone or in combination with insulin glargine results in similar glycemic control with less hypoglycemia than glargine and rapid-acting insulin with meals [66-68]. Our group first reported a pilot study in non-critical patients with blood glucose levels between 140 and $400 \mathrm{mg} / \mathrm{dl}$ treated with diet, oral antidiabetic drugs or low-dose insulin $(\leq 0.4 \mathrm{U} / \mathrm{kg} /$ day) who were randomized to sitagliptin once daily, sitagliptin and basal insulin, or basal-bolus insulin [66]. Doses of rapid insulin before meals and bedtime were used for correcting blood glucose $>140 \mathrm{mg} / \mathrm{dl}$. Sitagliptin alone or in combination with basal insulin resulted in similar mean daily blood glucose, hypoglycemia risk and treatment failures compared with the basal-bolus regimen. This study was followed by the SITA-HOSPITAL trial, a multicenter, randomized-controlled trial comparing sitagliptin and 
basal insulin to the more complex basal-bolus insulin regimen in patients with T2D [67]. A total of 279 patients previously treated with oral antidiabetic agents or low-dose insulin $(<0.6 \mathrm{U} /$ $\mathrm{kg} /$ day) and between 18 and 80 years of age were included. This strategy resulted in nonsignificant differences in the glycemic control, hypoglycemic rate, hospital length of stay, treatment failures and hospital complications compared with a standard basal-bolus regimen [67]. Additionally, it was associated with a significant reduction in both the total daily insulin dose and insulin injections [67]. Recently, Garg et al. [68] reported that treatment with saxagliptin in subjects with T2D and mild-tomoderate hyperglycemia was also associated with similar glucose control compared with basal or basal-bolus insulin therapy. This evidence indicates that the use of DPP4 inhibitors alone or in combination with basal insulin represents a new step in the future of inpatient hyperglycemia management [69]. Salient findings of these studies are shown in Table 3.

\section{SUMMARY}

Treatment intensification is a consistent need for patients with T2D. As $\beta$-cell function declines with disease progression, combination oral antidiabetic therapy is needed to attain glycemic control. Insulin therapy has historically been the next line of treatment alone or in combination with oral agents. Many studies have reported that weight gain and hypoglycemia may limit the ability to titrate insulin to achieve optimal glycemic control.

DPP4 inhibitor plus insulin is an effective and safe approach to optimize the management of glycemic control without increasing the risk of hypoglycemia or excessive weight gain. Most patients treated with this combination consistently showed a reduction in insulin requirement, better glycemic control, reduction in glycemic variability and a lower risk of hypoglycemia. The efficacy and safety of this combination have been proven with different DPP4 inhibitors, including alogliptin, sitagliptin,

Table 3 Salient data of studies of DPP4 inhibitors in hospitalized patients with T2D

\begin{tabular}{|c|c|c|c|}
\hline References & Design & Patients and treatment & Main findings \\
\hline $\begin{array}{l}\text { Umpierrez } \\
\qquad(2013) \\
{[66]}\end{array}$ & $\begin{array}{l}\text { Pilot randomized } \\
\text { study }\end{array}$ & $\begin{array}{l}90 \text { in-patients; sitagliptin alone or combined } \\
\text { with glargine or a basal-bolus (glargine and } \\
\text { lispro) both with correctional insulin doses }\end{array}$ & $\begin{array}{l}\text { No differences in glycemic control, } \\
\text { length of hospital stay and } \\
\text { hypoglycemia events } \\
\text { Fewer total daily insulin doses and } \\
\text { numbers of insulin injections in } \\
\text { sitagliptin groups }\end{array}$ \\
\hline $\begin{array}{l}\text { Pasquel } \\
\qquad(2017) \\
{[67]}\end{array}$ & $\begin{array}{l}\text { Non-inferiority } \\
\text { randomized- } \\
\text { controlled trial }\end{array}$ & $\begin{array}{l}277 \text { in-patients; sitagliptin plus basal glargine } \\
\text { once daily or basal-bolus (glargine and lispro) } \\
\text { both with correctional insulin doses }\end{array}$ & $\begin{array}{l}\text { Mean daily glucose concentration was } \\
\text { non-inferior } \\
\text { No differences in hospital } \\
\text { complications, length of stay, } \\
\text { hypoglycemic events and treatment } \\
\text { failures }\end{array}$ \\
\hline $\begin{array}{l}\text { Garg } \\
\qquad(2017) \\
{[68]}\end{array}$ & $\begin{array}{l}\text { Randomized- } \\
\text { controlled trial }\end{array}$ & $\begin{array}{l}66 \text { in-patients; saxagliptin or basal-bolus insulin } \\
\text { therapy, both with correctional insulin doses }\end{array}$ & $\begin{array}{l}\text { Non-inferior in mean daily blood } \\
\text { glucose control } \\
\text { Lower glycemic variability } \\
\text { Basal-bolus insulin: higher number of } \\
\text { injections and daily insulin dose }\end{array}$ \\
\hline
\end{tabular}


linagliptin, saxagliptin and vildagliptin in randomized, double-blind, placebo-controlled clinical studies. Rare but severe adverse events associated with DPP4 inhibitors such as pancreatitis, heart failure (saxagliptin) and bullous pemphigoid have been reported [8].

DPP4 inhibitors added to basal insulin improve glycemic control without increasing the risk of hypoglycemia. However, not all the studies showed consistent results. This may be due to the different protocols used.

It should be noted that insulin doses may be reduced when the DPP4 inhibitor + insulin combination is performed and that it also is recommended to reduce the dose of SU when DPP4 inhibitors are added to this treatment.

A subgroup of patients with a high risk of hypoglycemia, such as those with renal impairment and elderly patients, represents prime candidates to receive treatment with DPP4 inhibitors with or without low-dose insulin therapy. In addition, increasing evidence indicates that incretin-based therapies have the potential to improve glycemic control with a low risk of hypoglycemia in hospitalized patients with mild-to-moderate hyperglycemia [66-68].

\section{ACKNOWLEDGEMENTS}

Funding. No funding or sponsorship was received for this study or publication of this article.

Editorial Assistance. The authors thank Marta Pulido, MD, PhD, for editing the manuscript and editorial assistance.

Authorship. All named authors meet the International Committee of Medical Journal Editors (ICMJE) criteria for authorship for this article, take responsibility for the integrity of the work as a whole and have given their approval for this version to be published.

Disclosures. Fernando Gomez-Peralta has taken part in advisory panels for Sanofi and
Novo Nordisk; has received research support from Sanofi, Novo Nordisk, Boehringer Ingelheim Pharmaceuticals and Lilly; and has acted as a speaker for Sanofi, Novo Nordisk, Boehringer Ingelheim Pharmaceuticals, AstraZeneca Pharmaceuticals LP, Bristol-Myers Squibb Co. and Lilly. Cristina Abreu has received research support from Sanofi, Novo Nordisk, Boehringer Ingelheim Pharmaceuticals and Lilly and has acted as a speaker for Sanofi, Novo Nordisk, Boehringer Ingelheim Pharmaceuticals, AstraZeneca Pharmaceuticals LP and BristolMyers Squibb Co. Guillermo E. Umpierrez is partly supported by research grants from the Public Health Service (Grants UL1 TR002378 from the Clinical and Translational Science Award program and 1P30DK111024-01 from the National Institutes of Health and National Center for Research Resources). Guillermo E. Umpierrez has received unrestricted research support for inpatient studies (to Emory University) from Merck, Novo Nordisk, AstraZeneca, Boehringer Ingelheim, Insulcloud S.L. and Sanofi. Guillermo E. Umpierrez has received honoraria for being on the advisory board/a consultant from Sanofi, Intarcia and Jansen Pharmaceuticals. Rafael J. Barranco has nothing to disclose.

Compliance with Ethics Guidelines. This article is based on previously conducted studies and does not contain any studies with human participants or animals performed by any of the authors.

Data Availability. Data sharing is not applicable to this article as no data sets were generated or analyzed during the current study.

Open Access. This article is distributed under the terms of the Creative Commons Attribution-NonCommercial 4.0 International License (http://creativecommons.org/licenses/ by-nc/4.0/), which permits any noncommercial use, distribution, and reproduction in any medium, provided you give appropriate credit to the original author(s) and the source, provide a link to the Creative Commons license, and indicate if changes were made. 


\section{REFERENCES}

1. International Diabetes Federation. IDF Diabetes Atlas 2015. 7th ed. http://www.diabetesatlas.org. Accessed 10 Sept 2017.

2. DeFronzo RA, Eldor R, Abdul-Ghani M. Pathophysiologic approach to therapy in patients with newly diagnosed type 2 diabetes. Diabetes Care. 2013;36(Suppl 2):S127-38. https://doi.org/10.2337/ dcS13-2011.

3. Stratton IM, Adler AI, Neil HA, Matthews DR, Manley SE, Cull CA, et al. Association of glycaemia with macrovascular and microvascular complications of type 2 diabetes (UKPDS 35): prospective observational study. BMJ. 2000;321:405-12.

4. Lipska KJ, Yao X, Herrin J, McCoy RG, Ross JS, Steinman MA, et al. Trends in drug utilization, glycemic control, and rates of severe hypoglycemia, 2006-2013. Diabetes Care. 2017;40:468-75.

5. Koliaki C, Doupis J. Incretin-based therapy: a powerful and promising weapon in the treatment of type 2 diabetes mellitus. Diabetes Ther. 2011;2:101-21.

6. Vergès B, Bonnard C, Renard E. Beyond glucose lowering: glucagon-like peptide-1 receptor agonists, body weight and the cardiovascular system. Diabetes Metab. 2011;37:477-88.

7. Lee YS, Jun HS. Anti-diabetic actions of glucagonlike peptide- 1 on pancreatic beta-cells. Metabolism. 2014;63:9-19.

8. Dungan K, DeSantis A. Dipeptidyl peptidase-4 (DPP-4) inhibitors for the treatment of type 2 diabetes mellitus. UpToDate ${ }^{\circledR}$. June 12, 2017. https:// www.uptodate.com/contents/dipeptidyl-peptidase4-dpp-4-inhibitors-for-the-treatment-of-type-2-diabe tes-mellitus. Accessed 15 Sept 2017.

9. Holst JJ. The physiology of glucagon-like peptide. Physiol Rev. 2007;87:1409-39.

10. Campbell RK. Rationale for dipeptidyl peptidase 4 inhibitors: a new class of oral agents for the treatment of type 2 diabetes mellitus. Ann Pharmacother. 2007;41:51-60.

11. Raccah D. Basal insulin treatment intensification in patients with type 2 diabetes mellitus: a comprehensive systematic review of treatment options. Diabetes Metab. 2017;43:110-24.

12. Frandsen CS, Madsbad S. Efficacy and safety of dipeptidyl peptidase- 4 inhibitors as an add-on to insulin treatment in patients with type 2 diabetes: a review. Diabet Med. 2014;31:1293-300.
13. Inzucchi SE, Bergenstal RM, Buse JB, Diamant M, Ferrannini E, Nauck M, et al. Management of hyperglycaemia in type 2 diabetes, 2015: a patientcentred approach. Update to a position statement of the American Diabetes Association and the European Association for the Study of Diabetes. Diabetologia. 2015;58:429-42.

14. Higgins JPT, Green S. Cochrane handbook for systematic reviews of interventions. http://handbook5-1.cochrane.org/index.htm\#front_page.htm. Accessed 15 Sept 2017.

15. Keating GM. Alogliptin: a review of its use in patients with type 2 diabetes mellitus. Drugs. 2015;75:777-96.

16. Rosenstock J, Rendell MS, Gross JL, Fleck PR, Wilson CA, Mekki Q. Alogliptin added to insulin therapy in patients with type 2 diabetes reduces $\mathrm{HbA}(1 \mathrm{C})$ without causing weight gain or increased hypoglycaemia. Diabetes Obes Metab. 2009; 11:1145-52.

17. Kaku K, Mori M, Kanoo T, Katou M, Seino Y. Efficacy and safety of alogliptin added to insulin in Japanese patients with type 2 diabetes: a randomized, double-blind, 12-week, placebo-controlled trial followed by an open-label, long-term extension phase. Expert Opin Pharmacother. 2014;15:2121-30.

18. Vilsbøll T, Rosenstock J, Yki-Järvinen H, Cefalu WT, Chen Y, Luo E, et al. Efficacy and safety of sitagliptin when added to insulin therapy in patients with type 2 diabetes. Diabetes Obes Metab. 2010;12:167-77.

19. Hong ES, Khang AR, Yoon JW, Kang SM, Choi SH, Park KS, et al. Comparison between sitagliptin as add-on therapy to insulin and insulin dose-increase therapy in uncontrolled Korean type 2 diabetes: CSI study. Diabetes Obes Metab. 2012;14:795-802.

20. Sato S, Saisho Y, Kou K, Meguro S, Tanaka M, Irie J, et al. Efficacy and safety of sitagliptin added to insulin in Japanese patients with type 2 diabetes: the EDIT randomized trial. PLoS ONE. 2015;10:e0121988. https://doi.org/10.1371/ journal.pone.0121988.

21. Shankar RR, Bao Y, Han P, Hu J, Ma J, Peng Y, et al. Sitagliptin added to stable insulin therapy with or without metformin in Chinese patients with type 2 diabetes. J Diabetes Investig. 2017;8:321-9.

22. Mathieu C, Shankar RR, Lorber D, Umpierrez G, Wu $\mathrm{F}, \mathrm{Xu} \mathrm{L}$, et al. A randomized clinical trial to evaluate the efficacy and safety of co-administration of sitagliptin with intensively titrated insulin glargine. Diabetes Ther. 2015;6:127-42. 
23. Mori Y, Taniguchi Y, Miyazaki S, Yokoyama J, Utsunomiya K. Effects of add-on treatment with sitagliptin on narrowing the range of glucose fluctuations in Japanese type 2 diabetes patients receiving insulin therapy. Diabetes Technol Ther. 2013;15:237-40.

24. Yki-Järvinen H, Rosenstock J, Durán-Garcia S, Pinnetti S, Bhattacharya S, Thiemann S, et al. Effects of adding linagliptin to basal insulin regimen for inadequately controlled type 2 diabetes: $a \geq 52$ week randomized, double-blind study. Diabetes Care. 2013;36:3875-81.

25. Sheu WH, Park SW, Gong Y, Pinnetti S, Bhattacharya S, Patel S, et al. Linagliptin improves glycemic control after 1 year as add-on therapy to basal insulin in Asian patients with type 2 diabetes mellitus. Curr Med Res Opin. 2015;31:503-12.

26. Durán-Garcia S, Lee J, Yki-Järvinen H, Rosenstock J, Hehnke U, Thiemann S, et al. Efficacy and safety of linagliptin as add-on therapy to basal insulin and metformin in people with type 2 diabetes. Diabet Med. 2016;33:926-33.

27. Barnett AH, Charbonnel B, Donovan M, Fleming D, Chen R. Effect of saxagliptin as add-on therapy in patients with poorly controlled type 2 diabetes on insulin alone or insulin combined with metformin. Curr Med Res Opin. 2012;28:513-23.

28. Barnett AH, Charbonnel B, Li J, Donovan M, Fleming D, Iqbal N. Saxagliptin add-on therapy to insulin with or without metformin for type 2 diabetes mellitus: 52-week safety and efficacy. Clin Drug Investig. 2013;33:707-17.

29. Li FF, Jiang LL, Yan RN, Zhu HH, Zhou PH, Zhang DF, et al. Effects of saxagliptin add-on therapy to insulin on blood glycemic fluctuations in patients with type 2 diabetes: a randomized, control, openlabeled trial. Medicine (Baltim). 2016;95:e5229.

30. Fonseca V, Schweizer A, Albrecht D, Baron MA, Chang I, Dejager S. Addition of vildagliptin to insulin improves glycaemic control in type 2 diabetes. Diabetologia. 2007;50:1148-55.

31. Fonseca V, Baron M, Shao Q, Dejager S. Sustained efficacy and reduced hypoglycemia during one year of treatment with vildagliptin added to insulin in patients with type 2 diabetes mellitus. Horm Metab Res. 2008;40:427-30.

32. Kothny W, Foley J, Kozlovski P, Shao Q, Gallwitz B, Lukashevich $\mathrm{V}$. Improved glycaemic control with vildagliptin added to insulin, with or without metformin, in patients with type 2 diabetes mellitus. Diabetes Obes Metab. 2013;15:252-7.

33. Hirose T, Suzuki M, Tsumiyama I. Efficacy and safety of vildagliptin as an add-on to insulin with or without metformin in Japanese patients with type 2 diabetes mellitus: a 12-week, double-blind, randomized study. Diabetes Ther. 2015;6:559-71.

34. Ning G, Wang W, Li L, Ma J, Lv X, Yang M, et al. Vildagliptin as add-on therapy to insulin improves glycemic control without increasing risk of hypoglycemia in Asian, predominantly Chinese, patients with type 2 diabetes mellitus. J Diabetes. 2016;8:345-53.

35. Katsuno T, Ikeda H, Ida K, Miyagawa J, Namba M. Add-on therapy with the DPP-4 inhibitor sitagliptin improves glycemic control in insulin-treated Japanese patients with type 2 diabetes mellitus. Endocr J. 2013;60:733-42.

36. Chen TY, Hsieh CJ. Real-world effectiveness of sitagliptin as add-on therapy in patients with type 2 diabetes mellitus. Postgrad Med. 2014;126:205-15.

37. Gomez-Peralta F, Abreu C, Mora-Navarro G, LópezMorandeira P, Pérez-Gutiérrez E, Cordero-García B, Brito-Sanfiel M. Switching from premixed insulin to basal insulin analogue for type 2 diabetes and role of dipeptidyl peptidase-4 inhibitors. Exp Clin Endocrinol Diabetes. 2017. https://doi.org/10. 1055/s-0043-113453.

38. Muskiet MHA, Heerspink HJL, van Raalte DH. SGLT2 inhibition: a new era in renoprotective medicine? Lancet Diabetes Endocrinol. 2017;5(8):569-71.

39. Wu B, Bell K, Stanford A, Kern DM, Tunceli O, Vupputuri S, et al. Understanding CKD among patients with T2DM: prevalence, temporal trends, and treatment patterns-NHANES 2007-2012. BMJ Open Diabetes Res Care. 2016;4:e000154.

40. Betônico CC, Titan SM, Correa-Giannella ML, Nery M, Queiroz MS. Management of diabetes mellitus in individuals with chronic kidney disease: therapeutic perspectives and glycemic control. Clinics (Sao Paulo). 2016;71:47-53.

41. Lee AK, Lee CJ, Huang ES, Sharrett AR, Coresh J, Selvin E. Risk factors for severe hypoglycemia in black and white adults with diabetes: the Atherosclerosis Risk in Communities (ARIC) Study. Diabetes Care. 2017;40:1661-7.

42. Mikhail N. Use of dipeptidyl peptidase-4 inhibitors for the treatment of patients with type 2 diabetes mellitus and chronic kidney disease. Postgrad Med. 2012;124:138-44.

43. Abe M, Okada K. DPP-4 inhibitors in diabetic patients with chronic kidney disease and end-stage kidney disease on dialysis in clinical practice. Contrib Nephrol. 2015;185:98-115. 
44. Howse PM, Chibrikova LN, Twells LK, Barrett BJ, Gamble JM. Safety and efficacy of incretin-based therapies in patients with type 2 diabetes mellitus and CKD: a systematic review and meta-analysis. Am J Kidney Dis. 2016;68:733-42.

45. Kamiya H. A systematic review of the benefits and harms of dipeptidyl peptidase- 4 inhibitor for chronic kidney disease. Hemodial Int. 2017;21:72-83.

46. Chen M, Liu Y, Jin J, He Q. The efficacy and safety of dipeptidyl peptidase-4 inhibitors for treatment of type 2 diabetes mellitus patients with severe renal impairment: a meta-analysis. Ren Fail. 2016;38:581-7.

47. Cheng D, Fei Y, Liu Y, Li J, Chen Y, Wang X, et al. Efficacy and safety of dipeptidyl peptidase- 4 inhibitors in type 2 diabetes mellitus patients with moderate to severe renal impairment: a systematic review and meta-analysis. PLoS ONE. 2014;9:e111543. https://doi.org/10.1371/journal. pone.0111543.

48. Giorda CB, Nada E, Tartaglino B. Pharmacokinetics, safety, and efficacy of DPP-4 inhibitors and GLP-1 receptor agonists in patients with type 2 diabetes mellitus and renal or hepatic impairment. A systematic review of the literature. Endocrine. 2014;46:406-19.

49. McGill JB, Yki-Järvinen H, Crowe S, Woerle HJ, von Eynatten M. Combination of the dipeptidyl peptidase-4 inhibitor linagliptin with insulin-based regimens in type 2 diabetes and chronic kidney disease. Diabetes Vasc Dis Res. 2015;12:249-57.

50. Lukashevich V, Schweizer A, Foley JE, Dickinson S, Groop PH, Kothny W. Efficacy of vildagliptin in combination with insulin in patients with type 2 diabetes and severe renal impairment. Vasc Health Risk Manag. 2013;9:21-8.

51. Gómez Huelgas R, Martínez-Castelao A, Artola S, Górriz JL, Menéndez E. Treatment of type 2 diabetes mellitus in patients with chronic kidney disease. Grupo de Trabajo para el Documento de Consenso sobre el tratamiento de la diabetes tipo 2 en el paciente con enfermedad renal crónica. [Article in Spanish]. Med Clin (Barc). 2014;142:85.e1-10.

52. Gómez-Huelgas R, Gomez Peralta F, Rodríguez Mañas L, Formiga F, Puig Domingo M, Mediavilla Bravo JJ, Miranda C, Ena J. Treatment of type 2 diabetes mellitus in elderly patients [Article in Spanish]. Rev Clin Esp. 2018;218:74-88.

53. American Diabetes Association. 11. Older adults: Standards of Medical Care in Diabetes-2018. Diabetes Care. 2018;41(Suppl. 1):S119-25.
54. Ligthelm RJ, Kaiser M, Vora J, Yale JF. Insulin use in elderly adults: risk of hypoglycemia and strategies for care. J Am Geriatr Soc. 2012;60:1564-70.

55. Strain WD, Lukashevich V, Kothny W, Hoellinger MJ, Paldánius PM. Individualised treatment targets for elderly patients with type 2 diabetes using vildagliptin add-on or lone therapy (INTERVAL): a 24 week, randomised, double-blind, placebo-controlled study. Lancet. 2013;382:409-16.

56. Umpierrez GE, Cardona S, Chachkhiani D, Fayfman $\mathrm{M}$, Saiyed S, Wang $\mathrm{H}$, et al. A randomized controlled study comparing a DPP4 inhibitor (linagliptin) and basal insulin (glargine) in patients with type 2 diabetes in long-term care and skilled nursing facilities: linagliptin-LTC trial. J Am Med Dir Assoc. 2017. https://doi.org/10.1016/j.jamda. 2017.11.002.

57. Schweizer A, Dejager S, Foley JE, Shao Q, Kothny W. Clinical experience with vildagliptin in the management of type 2 diabetes in a patient population $\geq 75$ years: a pooled analysis from a database of clinical trials. Diabetes Obes Metab. 2011;13:55-64.

58. Barnett AH, Huisman H, Jones R, von Eynatten M, Patel S, Woerle HJ. Linagliptin for patients aged 70 years or older with type 2 diabetes inadequately controlled with common antidiabetes treatments: a randomised, double-blind, placebo-controlled trial. Lancet. 2013;382:1413-23.

59. Furnary AP, Gao G, Grunkemeier GL, Wu Y, Zerr KJ, Bookin SO, et al. Continuous insulin infusion reduces mortality in patients with diabetes undergoing coronary artery bypass grafting. J Thorac Cardiovasc Surg. 2003;125:1007-21.

60. Van den Berghe G, Wilmer A, Hermans G, Meersseman W, Wouters PJ, Milants I, et al. Intensive insulin therapy in the medical ICU. N Engl J Med. 2006;354:449-61.

61. Van den Berghe G, Wouters P, Weekers F, Verwaest C, Bruyninckx F, Schetz M, et al. Intensive insulin therapy in critically ill patients. $\mathrm{N}$ Engl J Med. 2001;345:1359-61.

62. Clement S, Braithwaite SS, Magee MF, Ahmann A, Smith EP, Schafer RG, et al. Management of diabetes and hyperglycemia in hospitals. Diabetes Care. 2004;27:553-91.

63. Umpierrez GE, Hellman R, Korytkowski MT, Kosiborod M, Maynard GA, Montori VM, et al. Management of hyperglycemia in hospitalized patients in non-critical care setting: an endocrine society clinical practice guideline. J Clin Endocrinol Metab. 2012;97:16-38. 
64. American Diabetes Association. 14. Diabetes care in the hospital. Diabetes Care. 2017;40(Suppl 1):S120-7.

65. Umpierrez GE, Smiley D, Jacobs S, Peng L, Temponi A, Mulligan P, et al. Randomized study of basalbolus insulin therapy in the inpatient management of patients with type 2 diabetes undergoing general surgery (RABBIT 2 surgery). Diabetes Care. 2011;34:256-61.

66. Umpierrez GE, Gianchandani R, Smiley D, Jacobs S, Wesorick DH, Newton C, et al. Safety and efficacy of sitagliptin therapy for the inpatient management of general medicine and surgery patients with type 2 diabetes: a pilot, randomized, controlled study. Diabetes Care. 2013;36:3430-5.
67. Pasquel FJ, Gianchandani R, Rubin DJ, Dungan KM, Anzola I, Gomez PC, et al. Efficacy of sitagliptin for the hospital management of general medicine and surgery patients with type 2 diabetes (Sita-Hospital): a multicentre, prospective, open-label, noninferiority randomised trial. Lancet Diabetes Endocrinol. 2017;5:125-33.

68. Garg R, Schuman B, Hurwitz S, Metzger C, Bhandari S. Safety and efficacy of saxagliptin for glycemic control in non-critically ill hospitalized patients. BMJ Open Diabetes Res Care. 2017;5:e000394. https://doi.org/10.1136/bmjdrc-2017-000394.

69. Nauck MA, Meier JJ. Sitagliptin plus basal insulin: simplifying in-hospital diabetes treatment? Lancet Diabetes Endocrinol. 2017;5:83-5. 